\title{
PENGARUH ADVERSITY QUOTIENT, EMOTIONAL QUOTIENT, DAN STRES TERHADAP PRESTASI AKADEMIK MAHASISWA ( STUDI KASUS PADA MAHASISWA YANG MENGIKUTI ORGANISASI MAHASISWA DI UNIVERSITAS AHMAD DAHLAN)
}

\author{
Ahmad Sudirman \\ sudirmanahmad313@gmail.com \\ Universitas Ahmad Dahlan \\ Ani Muttaqiyatun \\ animtq@gmail.com \\ Universitas Ahmad Dahlan
}

\begin{abstract}
ABSTRAK
This research main goals is to know the influence of an adversity quotient, emotional quotient and stress towards academic achievement among student who join organisations in Universitas Ahmad Dahlan. This research was a survey research using questionnaire as an instrument. Population of this research was a student who join organisation in Universitas Ahmad Dahlan. The sample that used was student who join an organisation such as DPM, BEM, HMPS and UKM from 2017 to 2018 school years that consist of 289 respondent with a proposional rundwon sampling technic. Instrument validation test was used pearson product moment, while the reliability was used alpha cronbach. Analysis technic that used was a mutiple reggresion analysis technic. The result of this research showing that adversity quotient variable (X1) has significant effect to academic achievement. emotional quotient variable (X2) has no significant effect to academic achievement. stress variable (X3) has significant effect to academic achievement. adversity quotient, emotional quotient and stress at the same time has a significant effect to academic achievement
\end{abstract}

Keyword : Adversity Quotient, Emotional Quotient, Stress, and Academic Achievement.

\begin{tabular}{l}
\hline \multicolumn{3}{c}{ PENDAHULUAN } \\
Pendidikan bisa didapatkan dari \\
mana saja, dari siapa saja, dan dalam \\
keadaan apa saja, baik itu secara \\
formal, informal, maupun nonformal. \\
Dengan pendidikan, diharapkan dapat \\
menghasilkan manusia yang berkualitas, \\
Sebagai negara hukum, Indonesia \\
mengatur hak setiap warga negara untuk \\
mengenyam bangku pendidikan pada \\
UU nomor 20 tahun 2003. Bahkan \\
mulai Juni 2015 pemerintah sudah \\
mulai mencanangkan wajib belajar 12 \\
tahun. Maksudnya, setiap warga negara \\
wajib mengikuti pendidikan formal \\
selama 12 tahun, dalam arti wajib \\
mendapatkan pendidikan formal sampai
\end{tabular}

jenjang Sekolah Menengah Atas (SMA). Mahasiswa semester awal biasanya mengikuti perkuliahan sesuai prosedur yaitu mengerjakan tugas yang diberikan oleh dosen dan mengumpulkannya tidak melebihi deadline, masuk ke ruang kelas tepat waktu dan memperhatikan penjelasan dosen di depan, belajar dengan giat saat akan memasuki masa ujian. Mahasiswa yang sudah lama atau biasanya dimulai pada semester 3 mereka sudah mulai banyak mengikuti kegiatan kampus seperti organisasi dan tugas tugas yang diberikan oleh dosenpun sudah mulai banyak kepada mahasiswa, hal ini tentu akan mempengaruhi prestasi mahasiswa tersebut. Membahas mengenai prestasi tidak akan terlepas dari pembahasan mengenai kecerdasan yang dimiliki seseorang. Namun berhasil atau tidaknya seseorang dalam 
meraih prestasinya tidak hanya bergantung pada kecerdasannya saja. Hal tersebut sejalan dengan Stolz (2000) yang menyatakan bahwa kesuksesan seseorang bukanya terletak pada Kecerdasan Intelegensinya (IQ) atau pada Kecerdasan Emosional (EQ) saja.

Setelah melakukan penelitian, Stolz menemukan faktor penentu kesuksesan seseorang salah satunya adalah daya usaha yang dimiliki orang itu atau biasa disebut dengan Adversity Quotient (AQ).

Menurut Goleman (2006) kecerdasan emosi merujuk pada kemampuan mengenali perasaan kita sendiri, dan kemampuan mengelola emosi dengan baik pada diri sendiri, dan dalam hubungan dengan orang lain. Menurut Abu (2009) intelegensi adalah daya penyesuaian diri dengan keadaan baru dengan menggunakan alatalat berfikir menurut tujuannya. Kenyataannya, dalam proses belajar mengajar di universitas sering ditemukan mahasiswa yang tidak dapat meraih prestasi belajar yang setara dengan kemampuan inteligensinya. Seperti faktor stres, stres dari perpektif orang biasa bisa digambarkan sebagai perasaan tegang, gelisah, atau khawatir. Menurut Handoko (2008) Stres adalah suatu kondisi ketegangan yang mempengarui emosi proses proses berfikir dan kondisi seseorang. pada umumnya orang menganggap stres merupakan suatu kondisi yang negatif yaitu kondisi yang mengarah ketimbulnya penyakit fisik maupun mental atau mengarah ke perilaku yang tidak wajar.

Menurut Winkel dalam Endah (2007) prestasi belajar adalah hasil dari suatu hasil penilaian dibidang pengetahuan, keterampilan, sikap sebagai hasil belajar yang dinyatakan dalam bentuk nilai. Melalui prestasi belajar seorang mahasiswa dapat mengetahui kemajuan-kemajuan yang telah dicapainya dalam belajar (Baitul, 2009).

\section{Rumusan Masalah}

1. Apakah ada pengaruh Adversity Quotient terhadap Prestasi Akademik Mahasiswa pada Mahasiswa yang mengikuti Organisasi Mahasiswa UAD?

2. Apakah ada pengaruh Emotional Quotient terhadap Prestasi Akademik Mahasiswa pada Mahasiswa yang mengikuti Organisasi Mahasiswa UAD?

3. Apakah ada pengaruh Stres terhadap Prestasi Akademik Mahasiswa pada Mahasiswa yang mengikuti Organisasi Mahasiswa UAD?

4. Apakah ada pengaruh Adversity Quotient, Emotional Quotient dan Stres terhadap Prestasi Akademik Mahasiswa pada Mahasiswa yang mengikuti Organisasi Mahasiswa UAD?

\section{REVIEW LITERATUR DAN HIPOTESIS}

\section{Landasan Teori}

\section{Adversity Quotient}

Adversity Quotient (AQ) adalah suatu teori yang dicetuskan oleh Paul G. Stoltz, Ph.D, seorang President of PEAK Learning Incorporated yang meraih gelar doktor dalam bidang komunikasi dan pengembangan organisasi. Stoltz juga telah menjadi konsultan dan pemimpin dalam bidang pemikiran untuk berbagai macam organisasi di seluruh dunia.

Menurut Stoltz (2000) IQ dan EQ tidak cukup untuk memprediksi kesuksesan seseorang, hal ini didukung setelah dilakukan riset selama 19 tahun dan penerapannya selama 10 tahun. Suksesnya pekerjaan dan hidup seseorang terutama ditentukan oleh Adversity Quotient (AQ).

Dimensi AQ Control (Kendali). Kendali umumnya bersifat internal dan seringnya sangat bersifat individual, karena diri sendirilah yang bisa 
mengendalikan respon yang diterima dari lingkungan. Harapan dan tindakan akan tumbuh jika diwadahi oleh suatu kemampuan yang dinamakan kendali (Stoltz, 2000).

Control atau kendali adalah kemampuan seseorang dalam mengendalikan dan mengelola sebuah peristiwa yang menimbulkan kesulitan di masa mendatang. Kendali diri ini akan berdampak pada tindakan selanjutnya atau respon yang dilakukan individu yang bersangkutan, tentang harapan dan idealitas individu untuk tetap berusaha keras mewujudkan keinginannya walau sesulit apapun keadaannya sekarang (Sho"imah, 2010).

Origin - Ownership (Asal Usul dan Pengakuan). Origin - Ownership atau biasa disebut $\mathrm{O} 2$ adalah satu kesatuan yang tidak bisa dipisahkan. Origin yaitu asal usul dari kesulitan yang dialami; siapa atau apa yang menyebabkan kesulitan itu terjadi. Hal ini dengan rasa bersalah. Rasa bersalah melihat sejauh mana seseorang mempermasalahkan dirinya, orang lain, atau lingkungannya saat menjadi kesulitan atau kegagalan yang dialami.

Rasa bersalah yang tepat akan menggugah seseorang untuk bertindak sedangkan rasa bersalah yang terlalu besar akan menciptakan kelumpuhan. Poin ini merupakan pembukaan dari poin ownership.

Ownership mengungkap sejauh mana seseorang mengakui akibatakibat kesulitan dan kesediaan seseorang untuk bertanggung jawab atas kesalahan atau kegagalan tersebut (Sho"imah, 2010). Reach (Jangkauan). Sejauh mana kesulitan ini akan merambah kehidupan seseorang menunjukkan bagaimana suatu masalah mengganggu aktivitas lainnya, sekalipun tidak berhubungan dengan masalah yang sedang dihadapi.

Adversity Quotient yang rendah pada individu akan membuat kesulitan merembes ke segi-segi lain dari kehidupan seseorang (Sho"imah, 2010).
Semakin rendah skor seseorang, semakin besar pula kemungkinan adanya anggapan bahwa peristiwa buruk yang terjadi adalah suatu bencana, dan setelah itu membiarkannya meluas pada situasi yang lain (Stoltz, 2000).

Endurance (Daya Tahan). Endurance mempertanyakan dua hal yang berkaitan, yaitu berapa lama kesulitan ini akan berlangsung dan berapa lama penyebab kesulitan ini akan berlangsung. Jika skor dimensi ini rendah, maka semakin besar kemungkinannya kesulitan atau penyebab-penyebab kesulitan yang dihadapi dianggap akan berlangsung lama (Stoltz, 2000).

Endurance melihat ketahanan individu, yaitu sejauh mana seseorang dapat memecahkan masalah. Dengan demikian aspek ini melihat berapa lama kesulitan dan penyebab kesulitan itu akan berlangsung. Hal ini berkaitan dengan pandangan individu terhadap kepermanenan dan ketemporeran kesulitan yang berlangsung. Efek dari aspek ini adalah pada harapan tentang baik atau buruknya keadaan masa depan. Makin tinggi daya tahan seseorang, makin mampu menghadapi berbagai kesukaran yang dihadapinya (Sho imah, 2010).

\section{Emotional Quotient}

Kecerdasan emosional adalah kemampuan seseorang mengatur kehidupan emosinya dengan inteligensi, menjaga keselarasan emosi dan pengungkapannya melalui keterampilan pengenalan diri, pengendalian diri, motivasi diri, empati dan keterampilan sosial (Goleman, 2002). Kemunculan istilah kecerdasanemosional dalam pendidikan, bagi sebagian orang mungkin dianggap sebagai jawaban atas kejanggalan tersebut. Teori Daniel Goleman, sesuai dengan judul bukunya, memberikan definisi baru terhadap kata cerdas. Mahasiswa yang mengikuti ORMAWA dalam menjalankan program kerjanya selalu yang berinteraksi dengan 
orang lain memerlukan tidak hanya IQ yang bagus namun EQ yang harus lebih bagus pula, dimana dalam menjalanka program kerjanya selalu melibatkan perasaan dan emosi sehingga setiap kali sehingga mahasiswa yang mengikuti ORMAWA dituntut untuk memiliki kecerdasan emosional yang tinggi.

\section{Stres Akademik}

a. Definisi Menurut Robbins (2005) dalam Angelica (2008) stres adalah kondisi dinamik yang didalamnya individu menghadapi peluang, kendala atau tanggung jawab beban kerja, dan diskripsi pekerjaan yang terkait dengan apa yang sangat diinginkan dan yang hasilnya dipersepsikan sebagai tidak pasti tetapi penting.

b. Cara Mengukur Skala Stres akademik ini di sesuaikan dengan pengertian stres akademik menurut Oon (2007) yaitu, suatu kondisi ketegangan yang dialami seorang siswa dalam mempersepsikan tuntutan akademik yang yang berupa tes, peringkat, pekerjaan rumah, ekspektasi, hubungan dengan teman sebaya dan guru. Variabel ini di ukur berdasarkan tiga penggolongan stres akademik yaitu: stress reaktif, stres kumulatif, stres insiden kritis.

\section{Prestasi Belajar}

Belajar dikatakan sebagai kegiatan yang berproses dan merupakan unsur yang sangat fundamental dalam setiap penyelenggaraan jenis dan jenjang pendidikan. Sebagian orang beranggapan bahwa belajar adalah semata-mata mengumpulkan atau menghafalkan faktafakta yang tersaji dalam bentuk informasi/materi pelajaran. (Muhibbin Syah, 2000). Kriteria mahasiswa berprestasi menurut DIKTI:

1) IPK. Indeks Prestasi Kumulatif (IPK) adalah seluruh nilai mata kuliah ratarata yang lulus sesuai dengan aturan masingmasing perguruan tinggi. IPK hanya dinilai dalam proses pemilihan
Mawapres sampai pemilihan tingkat perguruan tinggi.

2) Karya tulis Ilmiah yang merupakan tulisan ilmiah hasil dari kajian pustaka dari sumber terpercaya yang berisi solusi kreatif dari permasalahan yang dianalisis secara runtut dan tajam, serta diakhiri dengan kesimpulan yang relevan dengan tema yang ditentukan oleh panitia.

3) Prestasi/Kemampuan yang diunggulkan Prestasi/kemampuan yang diraih selama menjadi mahasiswa baik dalam kegiatan kurikuler, kokurikuler dan ekstrakurikuler sehingga mendapatkan pengakuan, penghargaan yang berdampak positif pada perguruan tinggi dan masyarakat. Dengan demikian prestasi yang dimaksud bukan sekadar berpartisipasi pada kegiatan tertentu, tetapi menjadi juara/finalis atau sekurangkurangnya mendapatkan predikat Jumlah prestasi maksimal 10 jenis.

4) Bahasa Inggris/Asing. Penilaian bahasa Inggris/Asing dilakukan melalui dua tahap yaitu (1) penulisan ringkasan (bukan abstrak) berbahasa Inggris/asing dari karya tulis ilmiah, dan (2) presentasi dan diskusi dalam bahasa Inggris/asing. Ringkasan berisi latar belakang, rumusan masalah, metodologi, hasil dan simpulan. Ringkasan terdiri atas 500-750 kata, ditulis dengan menggunakan 1,5 spasi di kertas berukuran A4. Dilengkapi Video yang diunggah berdurasi sekitar 5 menit untuk memberi gambaran tentang kemampuan/keterampilan peserta berbahasa Inggris/asing lainnya sesuai dengan bahasa yang digunakan pada penulisan ringkasan karya ilmiah.

5) Kepribadian. Kisi-kisi penilaian terdiri atas: sikap sesuai dengan prestasi yang dicapai, cenderung berpikiran maju, dan tidak menunjukkan perilaku yang tidak 
patut. Hasil penilaian kepribadian tidak dikuantifikasikan, tetapi dijadikan syarat untukmenentukan kepatutan sebagai Mawapres.

\section{Penelitian Terdahulu}

1. Adversity Quotient terhadap Prestasi Akademik Mahasiswa Dalam judul penelitian Pengaruh Adversity Quotient terhadap Prestasi Akademik Mahasiswa Fakultas Psikologi UIN SGD Bandung. Penulis Huda, Mulyana dalam penelitian ini adalah untuk mengetahui seberapa besar pengaruh adversity quotient terhadap prestasi akademik. Penelitian ini menggunakan metode korelasional dengan tipe kausalitas. Subjek penelitian berjumlah 147 mahasiswa Fakultas Psikologi UIN SGD Bandung angkatan 2013. Jumlah sampel penelitian sebanyak 109 orang, dipilih dengan teknik simple random sampling. AQ diukur dengan menggunakan skala Adversity Response Profile (ARP) Quick Take yang dimodifikasi untuk setting pendidikan.

Analisis statistik yang digunakan adalah analisis regresi sederhana. Berdasarkan pengolahan data dengan menggunakan SPSS versi 20, diperoleh nilai signifikansi $(0.029)<\alpha(0.05)$. Hal ini menunjukkan bahwa H0 ditolak, sehingga terdapat pengaruh signifikan Adversity Quotient terhadap prestasi akademik. Koefisien determinasi sebesar 0.044, menunjukkan pengaruh AQ terhadap prestasi akademik sebesar 4.4\%. Sehingga AQ termasuk pada faktor yang rendah dalam memengaruhi prestasi akademik.

\section{Emotional Quotient terhadap Prestasi} Akademik

a. Dalam judul penelitian Hubungan Kecerdasan Emosional Dengan Prestasi Akademik Pada Mahasiswa Keperawatan Di Banda Aceh. Penulis Ardia Putra dalam penelitian ini Kecerdasan emosional adalah suatu kemampuan untuk memotivasi diri sendiri dan bertahan menghadapi frustasi, mengendalikan dorongan hati dan tidak melebihlebihkan kesenangan, mengatur suasana hati dan menjaga agar beban stress tidak melumpuhkan kemampuan berpikir, berempati dan berdoa. Kecerdasan Emosional Meliputi: Kesadaran Diri, Mengelola Emosi, Memotivasi Diri, Empati dan Keterampilan Sosial. Tujuan Penelitian untuk mengetahui apakah ada hubungan antara kecerdasan emosional dengan prestasi akademik pada mahasiswa PSIK-FK Unsyiah Banda Aceh. Jenis penelitian studi korelasi, desain penelitian cross sectional study, jumlah sampel sebanyak 77 orang \& teknik pengambilan sampel Simple Random Sampling.

Pengumpulan data dengan menggunakan kuesioner dalam bentuk pernyataan. Analisa data dilakukan dengan penentuan nilai patokan sebagai dasar kategori. Hasil penelitian didapatkan tidak ada hubungan antara Kecerdasan Emosional dengan Indek Prestasi Akademik pada mahasiswa PSIKFK Unsyiah dengan nilai P-Value 0,$003 ; \alpha=0,05$. Hasil setiap subvariabel juga tidak memiliki hubungan antara kesadaran diri (PValue $=0,002)$, Mengelola Emosi (PValue $=0,379$ ), Memotivasi Diri (PValue $=0,003)$, Empati (P-Value $=$ 0,000), Keterampilan sosial (PValue $=0,088$ ) dengan Indek Prestasi Akademik. Rekomendasi kepada PSIK-FK Unsyiah agar dapat memberikan saran dan masukan kepada seluruh staf pengajar untuk meningkatkan keterampilan sosial antar sesama mahasiswa keperawatan dan sesama individu dalam bentuk tugas-tugas kelompok.

b. Dalam judul penelitian Pengaruh Kecerdasan Emosional Terhadap 
Prestasi Belajar Mahasiswa D-III Kebidanan Stikes Prima Nusantara Bukittinggi. Penulis Lismarni dengan hasil penelitian ini adalah Keberhasilan pendidikan dapat dilihat dari prestasi belajar yang telah dicapai. Dalam proses belajar, kecerdasan intelektual dan kecerdasan emosi saling melengkapi. Itu sebabnya Kecerdasan Intelektual (IQ) bukan merupakan satu-satunya faktor yang menentukan keberhasilan seseorang. IQ hanya menyumbang $20 \%$ bagi kesuksesan, sedangkan $80 \%$ adalah sumbangan faktor lain, diantaranya adalah Kecerdasan Emosional (EQ). Penelitian ini bertujuan untuk mengetahui pengaruh kecerdasan emosional terhadap prestasi belajar mahasiswa D-III Kebidanan STIKes Prima Nusantara.

Jenis penelitian ini adalah korelasional yang bersifat ex post facto. Populasi penelitian ini sebanyak 129 mahasiswa. Sampel yang diambil sebanyak 57 mahasiswa dengan metode Simple Random Sampling. Kriteria sampel pada penelitian ini adalah mahasiswa tingkat I yang masih terdaftar serta bersedia menjadi responden. Alat pengumpulan data yang digunakan adalah skala kecerdasan emosi dan arsip daftar nilai Indeks Prestasi semester II mahasiswa D-III Kebidanan STIKes Prima Nusantara.

Analisis data menggunakan teknik analisis korelasi pearson product moment. Berdasarkan perhitungan analisis pearson product moment, diperoleh hasil signifikansi (p) sebesar 0,042<0,05 dan koefisien korelasi (r) sebesar 0,270. Ini berarti terdapat hubungan kategori sedang antara kecerdasan emosi dengan prestasi belajar. Sedangkan arah hubungan adalah positif karena nilai $r$ adalah positif yang berarti semakin tinggi kecerdasan emosional semakin meningkat prestasi belajar. Disarankan bagi pengelola institusi pendidikan hendaknya mempertimbangkan metode-metode pengajaran yang didalamnya dapat menciptakan kondisi-kondisi pengembangan kompetensi mahasiswa yang berorientasi pada pengasahan kecerdasan emosi dalam upaya meningkatkan prestasi belajar mahasiswanya.

c. Dalam judul penelitian Pengaruh Kecerdasan Emosi Dan Stres Terhadap Prestasi Belajar Mahasiswa Jurusan Manajemen Ekstensi Fakultas Ekonomi Universitas Mulawarman (Studi Pada Mahasiswa Yang Telah Bekerja). Penulis Rusmin Nuryadin, dengan hasil penelitian ini adalah Pada level of significant 0,05 diperoleh thitung untuk variabel kecerdasan emosi (X1), sebesar 11,676 dan diketahui ttabel sebesar 1,67793 (Uji satu arah, pada kolom 4 dengan df 47), maka thitung > ttabel, dengan demikian variabel kecerdasan emosi (X1) terbukti berpengaruh positif dan signifikan terhadap variabel prestasi belajar (Y). Pada level of significant 0,05 diperoleh thitung untuk variabel stres (X2), sebesar -1,589 dan diketahui ttabel sebesar 1,67793 (Uji satu arah, pada kolom 4 dengan df 47), maka thitung < ttabel, dengan demikian variabel stres (X2) terbukti tidak berpengaruh signifikan terhadap variabel prestasi belajar (Y). Sesuai dengan hasil standardized coefficients beta menunjukkan bahwa kecerdasan emosi (X1) berpengaruh positif dan dominan terhadap prestasi belajar mahasiswa jurusan Manajemen Ekstensi Fakultas Ekonomi Universitas Mulawarman. 
3. Stres terhadap Prestasi Akademik

a. Dalam judul penelitian Pengaruh Stres, Motivasi, dan Kecerdasan Spiritual terhadap Prestasi Belajar pada Mahasiswa Jurusan Akuntansi Universitas Hasanuddin. Penelitian Fildzah S. , Rahmawati HS, dengan hasil Penelitian ini bertujuan untuk menganalisis pengaruh stres, motivasi, dan kecerdasan spiritual terhadap prestasi belajar pada mahasiswa Jurusan Akuntansi Univeristas Hasanuddin di Makassar. Penelitian ini dilaksanakan di Jurusan Akuntansi Universitas Hasanuddin Makassar. Populasi penelitian ini adalah mahasiswa Jurusan Akuntansi Universitas Hasanuddin Makassar yang telah melewati masa studi satu tahun dan belum memprogramkan skripsi.Teknik pengambilan sampel menggunakan purposive sampling. Data penelitian diperoleh dari kuesioner (primer).

Penelitian ini dilakukan dengan menggunakan analisis regresi linier berganda sebagai suatu model analisis. Hasil penelitian menunjukkan bahwa variabel stres, motivasi, dan kecerdasan spiritual berpengaruh signifikan terhadap prestasi belajar mahasiswa jurusan akuntansi pada tingkat signifikansi $0,000<0,05$.

\section{Hipotesis}

$\mathrm{H} 1$ : Adversity signifikan

Quotient berpengaruh Akademik terhadap Prestasi

H2: Emotional Quotient berpengaruh signifikan terhadap Prestasi Akademik

H3: Stres berpengaruh signifikan terhadap Prestasi Akademik

H4: Adversity Quotient, Emotional Quotient dan Stres berpengaruh signifikan terhadap Prestasi Akademik.

\section{METODE PENELITIAN \\ Populasi dan Sampel}

Populasi dalam penelitian ini adalah mahasiswa yang mengikuti organisasi di Universitas Ahmad Dahlan seperti BEM, DPM, HMPS, UKM Tahun Akademik 2017/2018 dimana total populasi 1667 dimana data ini di ambil dengan cara bertanya langsung pada pihak yang bersangkutan dan mengambil dari website organisasi (daftar website organisasi berada pada lampiran 15).

Sampel adalah bagian dari jumlah dan karakteristik yang dimiliki oleph populasi yang akan di selidiki dan dianggap bisa mewakili keseluruhan populasi. Sampel ini menggunakan tabel yang dikembangkan oleh Isaac dan Michael, Sampel dari penjelasan diatas dengan populasi 1667 dimana pada tabel angka tersebut tidak ada maka dibulatkan ke atas menjadi 1700 dimana margin of error atau tingkat kesalahan yang dipakai sebesar 5\% adalah 289. Teknik pengambilan sampel dengan proposional rundown sampling yaitu sampel yang di hitung berdasarkan perbandingan. Teknik ini di gunakan apabila populasi mempunyai anggota atau unsur yang tidak homogen dan berstrata secara proposional.

\section{Definisi Operasional}

1. Variabel Independen

Variabel dalam penelitian ini terdiri dari variabel independen (Y) dan variabel dependen $(\mathrm{X})$, yaitu:

$\mathrm{Y}$ : Prestasi Akademik

X1 : Adversity Quotient

X2 : Emotional Quotient

$\mathrm{X} 3$ : Stres

2. Variabel Dependen

\section{a. Adversity Quotient}

Menurut Stoltz (2000) AQ mempengaruhi, bahkan bisa menentukan daya saing, produktivitas seseorang, kreativitas, motivasi, bagaimana seseorang 
mengambil resiko, dan bagaimana melakukan perbaikan pada masa yang akan datang. AQ juga bisa memprediksi ketekunan, daya belajar dari suatu peristiwa, bagaimana merangkul perubahan yang ada, keuletan, stress dan tekanan yang dialami, serta kemunduran dirinya. Selain menurut Stoltz (2000) di atas, Stoltz (2000) juga membagi beberapa dimensi AQ yang dimana akan menjadi indikator variabel Adversity Quotient yaitu:

1) Control (Kendali).

2) Origin-Ownership (Asal dan Pengakuan).

3) Reach (Jangkauan).

4) Endurance (Daya Tahan).

\section{b. Emotional Quotient}

Kecerdasan emosional adalah kemampuan seseorang mengatur kehidupan emosinya dengan inteligensi, menjaga keselarasan emosi dan pengungkapannya melalui:

1) Keterampilan pengenalan diri.

2) Pengendalian diri.

3) Motivasi diri.

4) Empati.

5) Keterampilan sosial (Goleman 2002).

c. Stres

Cara mengukur stres akademik ini di sesuaikan dengan pengertian stres akademik menurut Oon (2007) yaitu, suatu kondisi ketegangan yang dialami seorang siswa dalam mempersepsikan tuntutan akademik yang yang berupa tes, peringkat, pekerjaan rumah, ekspektasi, hubungan dengan teman sebaya dan guru. Variabel ini di ukur berdasarkan tiga penggolongan stres akademik yaitu : stres reaktif, stres kumulatif, stres insiden kritis d. Prestasi Akademik

Kriteria mahasiswa berprestasi menurut Dikti ini akan menjadi indikator variabel prestasi akademik yaitu :

1) IPK

2) Karya tulis ilmiah

3) Prestasi/Kemampuan yang diunggulkan.

4) Bahasa Inggris / Asing

5) Kepribadian

\section{Uji Instrumen}

\section{Uji Validitas}

Uji Validitas untuk mengukur apakah data yang diperoleh valid atau tidak. Uji validitas ini menggunakan Pearson Product Moment, dimana dalam menentukan valid atau tidaknya dilihat dari nilai totalnya yaitu pada bagian Pearson Correlation. "Valid berarti instrument tersebut dapat digunakan untuk mengukur apa yang seharusnya diukur" Sugiyono (2012). Dalam uji validitas, indikator-indikator akan diuji. Indikator tersebut dikatakan valid apabila nilai $R$ hitung lebih besar dari pada R table (Adhila, 2014).

\section{Uji Reliabilitas}

Uji Reliabilitas instrument dapat dilakukan dengan menganalisis setiap butir-butir yang ada pada instrument dengan teknik tertentu (Sugiyono, 2012). Data dikatakan reliable atau dapat dipercaya ditentukan dengan nilai crobach alpha lebih besar sama dengan nilai batas standarisasi yang ditentukan yaitu 0,6 (Adhila, 2014).

\section{Teknik Analisis Data}

1. Analisis Regresi Berganda

Regresi Linear Berganda digunakan oleh peneliti. Bila peneliti bermaksud meramalkan bagaimana keadaaan (naik-turunya) variabel dependen bila dua atau lebih independen sebagai variabel independen (Sugiyono, 2008). Sehingga penelitian ini dapat dirumuskan dengan 
$\mathrm{Y} 1=\mathrm{a}+\mathrm{b} 1 \mathrm{X} 1+\mathrm{b} 2 \mathrm{X} 2+\mathrm{b} 3 \mathrm{X} 3+\mathrm{e}$

Keterangan:

$\mathrm{Y}=$ Variabel dependen

$\mathrm{a}=$ Konstanta

$\mathrm{b}=$ Koefisien

$\mathrm{X}=$ Variabel Independen

$\mathrm{e}=$ Standar Error

\section{Uji Hipotesis}

\section{Uji Parsial (Uji T)}

Uji $\mathrm{t}$ digunakan untuk menguji secara parsial masing-masing variabel. Hasil uji $\mathrm{t}$ dapat dilihat pada tabel coefficients pada kolom sig (significance). Jika probabilitas nilai $\mathrm{t}$ atau signifikansi < 0,05 (H0 ditolak dan Ha diterima), maka dapat dikatakan bahwa terdapat pengaruh antara variabel bebas terhadap variabel terikat secara parsial. Namun, jika probabilitas nilai $\mathrm{t}$ atau signifikansi $>0,05(\mathrm{H} 0$ diterima dan Ha ditolak), maka dapat dikatakan bahwa tidak terdapat pengaruh yang signifikan antara masing-masing variabel bebas terhadap variabel terikat.

2. Uji Simultan (Uji F)

Uji $F$ digunakan untuk mengetahui pengaruh variabel bebas secara bersama-sama (simultan) terhadap variabel terikat. Signifikan berarti hubungan yang terjadi dapat berlaku untuk populasi. Penggunaan tingkat signifikansinya beragam, tergantung keinginan peneliti, yaitu $0,01(1 \%) ; 0,05(5 \%)$ dan 0,10 (10\%). Hasil uji $\mathrm{F}$ dilihat dalam tabel ANOVA dalam kolom sig. Sebagai contoh, kita menggunakan taraf signifikansi 5\% $(0,05)$, jika nilai probabilitas < 0,05 (Ho ditolak dan Ha diterima), maka dapat dikatakan terdapat pengaruh yang signifikan secara bersama-sama antara variabel bebas terhadap variabel terikat. Namun, jika nilai signifikansi > 0,05 (Ho diterima dan Ha ditolak), maka tidak terdapat pengaruh yang signifikan secara bersama-sama antara variabel bebas terhadap variabel terikat.

\section{Uji Koefisien Determinasi}

Uji Koefisien determinasi pada intinya mengukur seberapa jauh kemampuan model dalam menerangkan variasi variabel dependen. Nilai koefisien determinasi adalah antara nol dan satu. Nilai R2 yang kecil berarti kemampuan variabel-variabel independen dalam menjelaskan variasi variabel dependen sangat terbatas. Nilai R2 yang mendekati satu berarti variabel-variabel independen memberikan hampir semua informasi yang dibutuhkan untuk memprediksi variasi variabel dependen (Ghozali, 2011).

\section{HASIL PENELITIAN DAN PEMBAHASAN}

\section{Hasil Analisis Responden}

\begin{tabular}{|c|c|c|c|}
\multicolumn{2}{|c|}{ Daftar Organisasi Mahasiswa di Universitas Ahmad Dahlan } \\
\hline Nama Organisasi & Website Organisasi & Jumlah & Sampel \\
\hline DPMF Psikologi & dpmfpsikologiuad (IG) & 15 & 4 \\
\hline BEMF Psikologi & bemf.psikologi.uad (IG) & 33 & 6 \\
\hline DPMF FTDI & Dpmftdi & 12 & 5 \\
\hline BEMF FTDI & Bemftdi & 23 & 5 \\
\hline HMPS Bahasa dan Sastra Arab & Hmps.bsa.uad & 9 & 3 \\
\hline HMPS Pendidikan Agama Islam & Hmpspaiuad & 25 & 5 \\
\hline HMPS Tafsir Hadist & Hmpsilhauad & 26 & 5 \\
\hline DPMF FEB & Dpmfeb.uad & 18 & 5 \\
\hline BEMF FEB & Bemfebuad & 36 & 6 \\
\hline HMPS Akuntansi & Hmpsakuntansiuad & 33 & 5 \\
\hline HMPS Manajemen & Hmpsm_uad & 31 & 4 \\
\hline HMPS Ekonomi Pembangunan & Hmepofficial & 31 & 5 \\
\hline DPMF FKIP & Dpmfkip_uad & 18 & 5 \\
\hline BEMF FKIP & Bem_fkip_uad & 44 & 5 \\
\hline HMPS Bimbingan Konseling & Hmpsbkuad & 44 & 6 \\
\hline HMPS Pendidikan Bahasa Inggris & Edsauad & 30 & 5 \\
\hline HMPS Pendidikan Bahasa dan Sastra & Hmpspbsiuad & 31 & 4 \\
\hline Indonesia & Hmps_p.biouad & 37 & 5 \\
\hline HMPS Pendidikan Biologi & Hmpspfisuad_- & 30 & 5 \\
\hline HMPS Pendidikan Fisika & & & \\
\hline
\end{tabular}




\begin{tabular}{|c|c|c|c|}
\hline HMPS Pendidikan Matematika & Mathematics_education & 19 & 3 \\
\hline HMPS Pendidikan Guru Paud & Hmps_pgpaud_uad & 23 & 5 \\
\hline HMPS Pendidikan Guru SD & Hmps_pgsduad & 42 & 4 \\
\hline $\begin{array}{l}\text { HMPS Pendidikan Pancasila dan } \\
\text { Kewarganegaraan }\end{array}$ & Hmps_ppln_uad & 37 & 5 \\
\hline DPMF Hukum & Dpmfhuad & 14 & 5 \\
\hline BEMF Hukum & Bemfhuad & 48 & 6 \\
\hline DPMF FSBK & Dpmfsbk.uad & 18 & 4 \\
\hline BEMF FSBK & Bemfsbk_uad & 33 & 5 \\
\hline HMPS Ilmu Komunikasi & Himakomuad & 18 & 5 \\
\hline HMPS Sastra Indonesia & Hmprisai & 18 & 4 \\
\hline HMPS Sastra Inggris & Hmsasinguad & 29 & 5 \\
\hline DPMF MIPA & dpmfmipauad & 10 & 3 \\
\hline BEMF MIPA & Bemipa_uad & 19 & 5 \\
\hline HMPS Biologi & Hmbiouad & 42 & 5 \\
\hline HMPS Fisika & Hmpsfisika_uad & 20 & 5 \\
\hline HMPS Matematika & Hmps.math.uad & 41 & 4 \\
\hline HMPS Sistem Informasi & Hmpssi_uad & 51 & 5 \\
\hline DPMF Farmasi & Dpmf_farmasiuad & 16 & 4 \\
\hline BEMF Farmasi & Farmasi_uad & 14 & 5 \\
\hline DPM FKM & Dpmflom_uad & 10 & 3 \\
\hline BEM FKM & Fkm_uad & 50 & 4 \\
\hline DPM FTI & Dpmftiuad & 12 & 5 \\
\hline BEM FTI & Bem.fti.uad & 24 & 5 \\
\hline DPM FKM & Dpmflk_uad & 10 & 3 \\
\hline BEM FKM & Fkm_uad & 50 & 4 \\
\hline DPM FTI & Dpmftiuad & 12 & 5 \\
\hline BEM FTI & Bem.fti.uad & 24 & 5 \\
\hline HMPS Teknik Elektro & Hmteuad & 34 & 4 \\
\hline HMPS Teknik Industri & Hmti.uad & 30 & 5 \\
\hline HMPS Teknik Informatika & Hmtifuad & 38 & 5 \\
\hline HMPS Teknik Kimia & Hmtk_uad & 33 & 4 \\
\hline HMPS Teknik Pangan & Hmtpuad & 30 & 5 \\
\hline UKM Badminton & Badminton_uad & 20 & 5 \\
\hline UKM Bola Basket & Ukmbasketuad & 11 & 3 \\
\hline UKM Voli & Ukmvoli_uad & 20 & 5 \\
\hline UKM Karate & Karate.uad & 30 & 5 \\
\hline UKM Kopma & Kopmauad & 23 & 4 \\
\hline UKM Lensa & Lensauad & 22 & 5 \\
\hline UKM Madapala & Madapalauad & 10 & 3 \\
\hline UKM Menwa & Menwa_uad & 23 & 4 \\
\hline UKM Musik & Mabesmusikuad & 15 & 5 \\
\hline UKM PMI & Ksr_pmi_unit_x_uad & 20 & 4 \\
\hline UKM Pramuka & Pramukauad & 45 & 5 \\
\hline UKM PSM & Ahdagitana & 47 & 4 \\
\hline UKM Poros & Porosuad & 6 & 3 \\
\hline UKM Seni Tari & Ukmtariuad & 14 & 5 \\
\hline UKM Sepak Bola & Ukmsepakbolauad & 40 & 5 \\
\hline UKM Take Kwondo & taekwondouad & 22 & 4 \\
\hline TOTAL & 63 Organisasi & 1667 & 289 \\
\hline
\end{tabular}

Dari data diatas dapat jelaskan bahwa populasi pada penelitian ini sebanyak 1667 dengan sampel 289 mahasiswa yang mengikuti organiasasi seperti DMP Fakultas, Bem Fakultas, HMPS dan UKM. Dari sampel 289 di bagi lagi komposisinya sehingga semua organisasi dapat terwakilkan, untuk jumlah sampel yang dapat mewakili dapat dilihat di tabel atas. Responden pada penelitian ini adalah mahasiswa yang mengikuti organisasi pada Tahun 2017/2018.

\section{Hasil Penelitian}

1. Hasil Uji Validitas

a. Uji Validitas Variabel Adversity Quotient (AQ)

Dari variabel tersebut, terdapat 24 item pernyataan yang digunakan dalam kuisioner. Item tersebut terdiri dari AQ1, AQ2, AQ3, AQ4, AQ5, AQ6, AQ7, AQ8, AQ9, AQ10, AQ11, AQ12, AQ13, AQ14, AQ15, AQ16, AQ17, AQ18, AQ19, AQ20, AQ21, AQ22, AQ23, dan AQ24. Hasil uji validitas variabel Adversity Quotient yaitu sebagai berikut.

Tabel Hasil Uji Validitas Adversity Quotient Tahap 1

\begin{tabular}{|l|l|l|l|}
\hline $\begin{array}{l}\text { Butir } \\
\text { Pernyataan }\end{array}$ & $\begin{array}{l}\text { Pearson } \\
\text { Correlation }\end{array}$ & R tabe1 & Keterangan \\
\hline AQ1 & 0,050 & 0,374 & Tidak Valid \\
\hline AQ2 & 0,020 & 0,374 & Tidak Valid \\
\hline AQ3 & 0,507 & 0,374 & Valid \\
\hline AQ4 & 0,217 & 0,374 & Tidak Valid \\
\hline AQ5 & 0,436 & 0,374 & Valid \\
\hline AQ6 & 0,530 & 0,374 & Valid \\
\hline AQ7 & 0,562 & 0,374 & Valid \\
\hline AQ8 & 0,529 & 0,374 & Valid \\
\hline AQ9 & 0,164 & 0,374 & Tidak Valid \\
\hline AQ10 & 0,303 & 0,374 & Tidak Valid \\
\hline AQ11 & 0,520 & 0,374 & Valid \\
\hline AQ12 & 0,064 & 0,374 & Tidak Valid \\
\hline AQ13 & 0,278 & 0,374 & Tidak Valid \\
\hline AQ14 & 0,148 & 0,374 & Tidak Valid \\
\hline AQ15 & 0,333 & 0,374 & Tidak Valid \\
\hline AQ16 & 0,105 & 0,374 & Tidak Valid \\
\hline AQ17 & 0,297 & 0,374 & Tidak Valid \\
\hline AQ18 & 0,532 & 0,374 & Valid \\
\hline AQ19 & 0,392 & 0,374 & Valid \\
\hline AQ20 & 0,380 & 0,374 & Valid \\
\hline AQ21 & 0,646 & 0,374 & Valid \\
\hline AQ22 & 0,755 & 0,374 & Valid \\
\hline AQ23 & 0,595 & 0,374 & Valid \\
\hline AQ24 & 0,262 & 0,374 & Tidak Valid \\
\hline & Sumber: Data Primer, 2018 \\
\hline
\end{tabular}

Dari hasil output diatas terlihat ada 12 pernyataan yang tidak valid. Maka pernyataan-pernyataan tersebut harus dikeluarkan / dihapus dan mengulang proses yang sama. Pernyataan yang dianggap tidak valid yaitu yang memiliki nilai pearson correlation / $\mathrm{r}$ hitung lebih kecil dari $r$ tabel, diantaranya yaitu AQ1 dengan nilai $r$ hitung sebesar 0,050 , AQ2 dengan nilai $r$ hitung 0,020, AQ4 dengan nilai $r$ hitung sebesar 0,217, AQ9 dengan nilai $r$ hitung sebesar 0,164, AQ10 dengan nilai $r$ hitung sebesar 0,303 , AQ12 dengan nilai $\mathrm{r}$ hitung sebesar 0,064 , AQ13 dengan nilai $r$ hitung sebesar 0,278, AQ14 dengan nilai $r$ hitung 
sebesar 0,148, AQ15 dengan nilai $r$ hitung sebesar 0,333, AQ16 dengan nilai $\mathrm{r}$ hitung sebesar 0,105 , AQ17 dengan nilai $r$ hitung sebesar 0,297 , dan AQ24 dengan nilai $r$ hitung sebesar 0,262 yang dimana semua nilai tersebut lebih kecil dari $r$ tabel sebesar 0,374.

Setelah

penghapusan pernyataan AQ1, AQ2, AQ4,AQ9, AQ10, AQ12,AQ13, AQ14, AQ15, AQ16, AQ17, dan AQ24 hasil yang baru seperti yang ada pada tabel 4.2 dibawah ini.

Tabel Hasil Uji Validitas Adversity Quotient Tahap 2

\begin{tabular}{|l|l|l|l|}
\hline $\begin{array}{l}\text { Butir } \\
\text { Pernyataan }\end{array}$ & $\begin{array}{l}\text { Pearson } \\
\text { Correlation }\end{array}$ & R tabel & Keterangan \\
\hline AQ3 & 0,549 & 0,374 & Valid \\
\hline AQ5 & 0,395 & 0,374 & Valid \\
\hline AQ6 & 0,688 & 0,374 & Valid \\
\hline AQ7 & 0,442 & 0,374 & Valid \\
\hline AQ8 & 0,611 & 0,374 & Valid \\
\hline AQ11 & 0,511 & 0,374 & Valid \\
\hline AQ18 & 0,656 & 0,374 & Valid \\
\hline AQ19 & 0,487 & 0,374 & Valid \\
\hline AQ20 & 0,502 & 0,374 & Valid \\
\hline AQ21 & 0,748 & 0,374 & Valid \\
\hline AQ22 & 0,761 & 0,374 & Valid \\
\hline AQ23 & 0,699 & 0,374 & Valid \\
\hline
\end{tabular}

Dari hasil output diatas terlihat bahwa tiap butir pernyataan adalah valid karena diatas nilai $r$ tabel $(0,374)$. Pernyataan yang dianggap valid yaitu yang memiliki nilai pearson correlation / $\mathrm{r}$ hitung lebih besar dari $r$ tabel. Sehingga 12 pernyataan tersebut dapat digunakan untuk mengukur variabel Adversity Quotient.

b. Uji Validitas Variabel Emotional Quotient (EQ)

Dari variabel tersebut, terdapat 27 item pernyataan yang digunakan dalam kuisioner. Item tersebut terdiri dari EQ1, EQ2, EQ3, EQ4, EQ5, EQ6, EQ7, EQ8, EQ9, EQ10, EQ11, EQ12, EQ13, EQ14, EQ15, EQ16, EQ17, EQ18, EQ19, EQ20, EQ21, EQ22, EQ23, EQ24, EQ25, EQ26, dan EQ27. Hasil uji validitas variabel Emotional Quotient yaitu sebagai berikut.

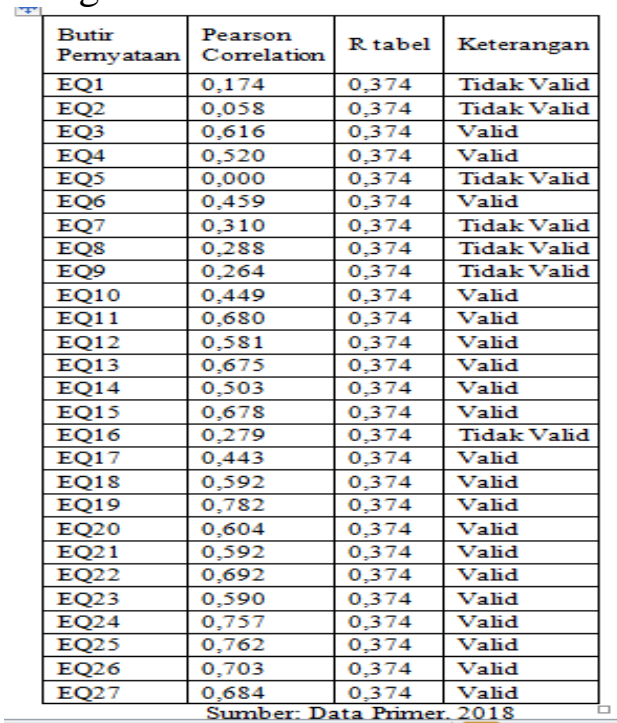

Dari hasil output diatas terlihat ada 7 pernyataan yang tidak valid. Maka pernyataan-pernyataan tersebut harus dikeluarkan / dihapus dan mengulang proses yang sama. Pernyataan yang dianggap tidak valid yaitu yang memiliki nilai pearson correlation / $\mathrm{r}$ hitung lebih kecil dari $r$ tabel, diantaranya yaitu EQ1 dengan niali $r$ hitung sebesar 0,174 , EQ2 dengan nilai $\mathrm{r}$ hitung 0,058 , EQ5 dengan nilai $r$ hitung sebesar 0,000, EQ7 dengan nilai $r$ hitung sebesar 0,310, EQ8 dengan nilai $\mathrm{r}$ hitung sebesar 0,288, EQ9 dengan nilai $\mathrm{r}$ hitung sebesar 0,264 , dan EQ16 dengan nilai $r$ hitung sebesar 0,279, yang dimana semua nilai tersebut lebih kecil dari $\mathrm{r}$ tabel sebesar 0,374. Setelah penghapusan pernyataan EQ1, EQ2, EQ5, EQ7, EQ8, EQ9, dan EQ16, hasil yang baru seperti yang ada pada tabel 4.4 dibawah ini. 


\begin{tabular}{|l|l|l|l|}
\hline $\begin{array}{l}\text { Butir } \\
\text { Pernyataan }\end{array}$ & $\begin{array}{l}\text { Pearson } \\
\text { Correlation }\end{array}$ & R tabel & Keterangan \\
\hline EQ3 & 0,641 & 0,374 & Valid \\
\hline EQ4 & 0,459 & 0,374 & Valid \\
\hline EQ6 & 0,423 & 0,374 & Valid \\
\hline EQ10 & 0,388 & 0,374 & Valid \\
\hline EQ11 & 0,594 & 0,374 & Valid \\
\hline EQ12 & 0,642 & 0,374 & Valid \\
\hline EQ13 & 0,658 & 0,374 & Valid \\
\hline EQ14 & 0,567 & 0,374 & Valid \\
\hline EQ15 & 0,670 & 0,374 & Valid \\
\hline EQ17 & 0,469 & 0,374 & Valid \\
\hline EQ18 & 0,670 & 0,374 & Valid \\
\hline EQ19 & 0,829 & 0,374 & Valid \\
\hline EQ20 & 0,656 & 0,374 & Valid \\
\hline EQ21 & 0,635 & 0,374 & Valid \\
\hline EQ22 & 0,755 & 0,374 & Valid \\
\hline
\end{tabular}

\begin{tabular}{|l|l|l|l|}
\hline EQ23 & 0,584 & 0,374 & Valid \\
\hline EQ24 & 0,750 & 0,374 & Valid \\
\hline EQ25 & 0,748 & 0,374 & Valid \\
\hline EQ26 & 0,725 & 0,374 & Valid \\
\hline EQ27 & 0,722 & 0,374 & Valid \\
\hline \multicolumn{4}{|c|}{ Sumber: Data Primer, 2018 }
\end{tabular}

Dari hasil output diatas terlihat bahwa tiap butir pernyataan adalah valid karena diatas nilai $r$ tabel $(0,374)$. Pernyataan yang dianggap valid yaitu yang memiliki nilai pearson correlation / $\mathrm{r}$ hitung lebih besar dari $r$ tabel. Sehingga 20 pernyataan tersebut dapat digunakan untuk mengukur variabel Emotional Quotient.

c. Uji Validitas Variabel Stres (S)

Variabel kinerja terdapat 17 item pernyataan yang digunakan dalam kuisioner yaitu $\mathrm{S} 1, \mathrm{~S} 2, \mathrm{~S} 3, \mathrm{~S} 4$, S5, S6, S7, S8, S9, S10, S11, S12, S13, S14, S15, S16, dan S17. Hasil uji validitas variabel stres, sebagai berikut.

\begin{tabular}{|l|l|l|l|}
\hline $\begin{array}{l}\text { Butir } \\
\text { Pernyataan }\end{array}$ & $\begin{array}{l}\text { Pearson } \\
\text { Correlation }\end{array}$ & R tabel & Keterangan \\
\hline S1 & 0,525 & 0,374 & Valid \\
\hline S2 & 0,620 & 0,374 & Valid \\
\hline S3 & 0,445 & 0,374 & Valid \\
\hline S4 & 0,155 & 0,374 & Tidak Valid \\
\hline S5 & 0,664 & 0,374 & Valid \\
\hline S6 & 0,644 & 0,374 & Valid \\
\hline S7 & 0,713 & 0,374 & Valid \\
\hline S8 & 0,020 & 0,374 & Tidak Valid \\
\hline S9 & 0,239 & 0,374 & Tidak Valid \\
\hline S10 & 0,297 & 0,374 & Tidak Valid \\
\hline S11 & 0,616 & 0,374 & Valid \\
\hline S12 & 0,371 & 0,374 & Tidak Valid \\
\hline
\end{tabular}

\begin{tabular}{|l|l|l|l|}
\hline S13 & 0,064 & 0,374 & Tidak Valid \\
\hline S14 & 0,382 & 0,374 & Valid \\
\hline S15 & 0,124 & 0,374 & Tidak Valid \\
\hline S16 & 0,453 & 0,374 & Valid \\
\hline S17 & 0,522 & 0,374 & Valid \\
\hline \multicolumn{4}{|c|}{ Sumber: Data Primer, 2018}
\end{tabular}

Dari hasil output diatas terlihat ada 7 pernyataan yang tidak valid. Maka pernyataan tersebut harus dikeluarkan / dihapus dan proses harus diulang lagi. Pernyataan yang dianggap tidak valid yaitu yang memiliki nilai pearson correlation / $\mathrm{r}$ hitung lebih kecil dari $r$ tabel, diantaranya yaitu $\mathrm{S} 4$ dengan nilai $r$ hitung sebesar 0,155, S8 dengan nilai $r$ hitung sebesar $0,020, \quad S 9$ dengan nilai $\mathrm{r}$ hitung sebesar 0,239 , S10 yang dimana nilai tersebut lebih kecil dari $r$ tabel sebesar 0,297, S12 yang dimana nilai tersebut lebih kecil dari $r$ tabel sebesar 0,371, S13 yang dimana nilai tersebut lebih kecil dari $r$ tabel sebesar 0,064 dan S15 yang dimana nilai tersebut lebih kecil dari $r$ tabel sebesar 0,124 .

Setelah penghapusan pernyataan S4, S8,S9, S10, S12,S13 dan S15 hasil yang baru seperti yang ada pada tabel 4.6 dibawah ini.

\begin{tabular}{|l|l|l|l|}
\hline $\begin{array}{l}\text { Butir } \\
\text { Pernyataan }\end{array}$ & $\begin{array}{l}\text { Pearson } \\
\text { Correlation }\end{array}$ & R tabel & Keterangan \\
\hline S1 & 0,537 & 0,374 & Valid \\
\hline S2 & 0,779 & 0,374 & Valid \\
\hline S3 & 0,684 & 0,374 & Valid \\
\hline S5 & 0,650 & 0,374 & Valid \\
\hline S6 & 0,777 & 0,374 & Valid \\
\hline S7 & 0,843 & 0,374 & Valid \\
\hline
\end{tabular}

Dari hasil output diatas terlihat bahwa tiap butir pernyataan adalah valid karena diatas nilai $r$ tabel $(0,374)$. Pernyataan yang dianggap valid yaitu yang memiliki nilai pearson correlation / $\mathrm{r}$ hitung lebih besar dari $r$ tabel. Sehingga 10 pernyataan tersebut dapat digunakan untuk mengukur variabel stres. 
d. Uji Validitas Variabel Prestasi Akademik (PA)

Variabel kinerja terdapat 10 item pernyataan yang digunakan dalam kuisioner yaitu PA1, PA2, PA3, PA4, PA5, PA6, PA7, PA8, PA9, dan PA10. Hasil uji validitas variabel stres, sebagai berikut.

\begin{tabular}{|l|l|l|l|}
\hline $\begin{array}{l}\text { Butir } \\
\text { Pernyataan }\end{array}$ & $\begin{array}{l}\text { Pearson } \\
\text { Correlation }\end{array}$ & R tabel & Keterangan \\
\hline PA1 & 0,227 & 0,374 & Tidak Valid \\
\hline PA2 & 0,650 & 0,374 & Valid \\
\hline PA3 & 0,529 & 0,374 & Valid \\
\hline PA4 & 0,490 & 0,374 & Valid \\
\hline PA5 & 0,626 & 0,374 & Valid \\
\hline PA6 & 0,597 & 0,374 & Valid \\
\hline PA7 & 0,187 & 0,374 & Tidak Valid \\
\hline PA8 & 0,625 & 0,374 & Valid \\
\hline PA9 & 0,570 & 0,374 & Valid \\
\hline PA10 & 0,428 & 0,374 & Valid \\
\hline
\end{tabular}

Dari hasil output diatas terlihat ada 2 pernyataan yang tidak valid. Maka pernyataan tersebut harus dikeluarkan / dihapus dan proses harus diulang lagi. Pernyataan yang dianggap tidak valid yaitu yang memiliki nilai pearson correlation / $\mathrm{r}$ hitung lebih kecil dari $r$ tabel, diantaranya yaitu PA1 dengan nilai $r$ hitung sebesar 0,227 dan PA7 dengan nilai $r$ hitung sebesar 0,187. Setelah penghapusan pernyataan PA1 dan PA7, hasil yang baru seperti yang ada pada tabel 4.8 dibawah ini.

\begin{tabular}{|l|l|l|l|}
\hline $\begin{array}{l}\text { Butir } \\
\text { Pernyataan }\end{array}$ & $\begin{array}{l}\text { Pearson } \\
\text { Correlation }\end{array}$ & R tabel & Keterangan \\
\hline PA2 & 0,622 & 0,374 & Valid \\
\hline PA3 & 0,627 & 0,374 & Valid \\
\hline PA4 & 0,484 & 0,374 & Valid \\
\hline PA5 & 0,689 & 0,374 & Valid \\
\hline PA6 & 0,649 & 0,374 & Valid \\
\hline PA8 & 0,559 & 0,374 & Valid \\
\hline PA9 & 0,704 & 0,374 & Valid \\
\hline PA10 & 0,429 & 0,374 & Valid \\
\hline
\end{tabular}

Dari hasil output diatas terlihat bahwa tiap butir pernyataan adalah valid karena diatas nilai $\mathrm{r}$ tabel $(0,374)$. Pernyataan yang dianggap valid yaitu yang memiliki nilai pearson correlation / $\mathrm{r}$ hitung lebih besar dari $r$ tabel. Sehingga 6 pernyataan tersebut dapat digunakan untuk mengukur variabel stres.
Hasil Uji Validitas

\begin{tabular}{|c|c|c|c|c|c|c|}
\hline Variabel & Pernyataan & \multicolumn{3}{|c|}{ Pearson correlation } & Status \\
\hline & & & & & & \\
\hline Adversity Quotient & $\mathrm{AQ} 3$ & 0,549 & & & & Valid \\
\hline & $\mathrm{AQ5}$ & 0,395 & & & & Valid \\
\hline & $\mathrm{AQ6}$ & 0,688 & & & & Valid \\
\hline & $\mathrm{AQ7}$ & 0,442 & & & & Valid \\
\hline & $\mathrm{AQ} 8$ & 0,611 & & & & Valid \\
\hline
\end{tabular}

\begin{tabular}{|c|c|c|c|c|}
\hline & AQ11 & 0,511 & & Valid \\
\hline & AQ18 & 0,656 & & Valid \\
\hline & AQ19 & 0,487 & & Valid \\
\hline & $\mathrm{AQ} 20$ & 0,502 & & Valid \\
\hline & AQ21 & 0,748 & & Valid \\
\hline & $\mathrm{AQ} 22$ & 0,761 & & Valid \\
\hline & AQ23 & 0,699 & & Valid \\
\hline \multirow[t]{20}{*}{ Emotional Quotient } & $\mathrm{EQ}^{3}$ & & 0,641 & Valid \\
\hline & EQ4 & & 0,459 & Valid \\
\hline & EQ6 & & 0,423 & Valid \\
\hline & EQ10 & & 0,388 & Valid \\
\hline & EQ11 & & 0,594 & Valid \\
\hline & EQ12 & & 0,642 & Valid \\
\hline & EQ13 & & 0,658 & Valid \\
\hline & EQ14 & & 0,567 & $\begin{array}{l}\text { Valid } \\
\end{array}$ \\
\hline & EQ15 & & 0,670 & Valid \\
\hline & EQ17 & & 0,469 & Valid \\
\hline & EQ18 & & 0,670 & Valid \\
\hline & EQ19 & & 0,829 & Valid \\
\hline & EQ20 & & 0,656 & Valid \\
\hline & EQ21 & & 0,635 & Valid \\
\hline & EQ22 & & 0,755 & Valid \\
\hline & EQ23 & & 0,584 & Valid \\
\hline & EQ24 & & 0,750 & Valid \\
\hline & EQ25 & & 0,748 & Valid \\
\hline & EQ26 & & 0,725 & Valid \\
\hline & EQ27 & & 0,722 & Valid \\
\hline
\end{tabular}

\begin{tabular}{|l|c|l|l|l|l|l|}
\hline & PA4 & & & & 0,484 & Valid \\
\hline & PA5 & & & & 0,689 & Valid \\
\hline & PA6 & & & & 0,649 & Valid \\
\hline & PA8 & & & & 0,559 & Valid \\
\hline & PA9 & & & & 0,704 & Valid \\
\hline & PA10 & & & 0,429 & Valid \\
\hline
\end{tabular}

Berdasarkan tabel 4.9 dapat diketahui bahwa setiap butir pernyataan dari 4 variabel adalah valid dan tidak ada yang dihapuskan karena nilai pearson correlation/ $r$ hitung lebih besar dari nilai $r$ tabel.

2. Hasil Uji Realibilitas

Hasil Uji Reliabilitas pada Seluruh Variabel Penelitian

\begin{tabular}{|c|c|c|c|}
\hline No & Variabel & $\begin{array}{c}\text { Cronbach's } \\
\text { Alpha }\end{array}$ & Keterangan \\
\hline 1 & Adversity Quotient $\left(\mathrm{X}_{1}\right)$ & 0,805 & Reliabel \\
\hline 2 & Emotional Quotient $\left(\mathrm{X}_{2}\right)$ & 0,919 & Reliabel \\
\hline 3 & Stres $\left(\mathrm{X}_{3}\right)$ & 0,760 & Reliabel \\
\hline 4 & Prestasi Akademik $(\mathrm{Y})$ & 0,735 & Reliabel \\
\hline
\end{tabular}

Dari tabel diatas maka hasil uji reliabilitas dapat dijelaskan sesuai dengan nilai Cronbach's Alpha variabel sebagai berikut.

1. Adversity Quotient, nilai yang dihasilkan oleh variabel ini sebesar 0,805 . Sesuai dengan ketentuan yaitu 
0,805 lebih besar dari 0,60 sehingga hasil dari variabel tanggap dalam pengujian yaitu reliabel. Dalam variabel ini setiap pernyataan dan jawaban konsisten.

2. Emotional Quotient, nilai yang dihasilkan oleh variabel ini sebesar 0,919 . Sesuai dengan ketentuan yaitu 0,919 lebih besar dari 0,60 sehingga hasil dari variabel tanggap dalam pengujian ini yaitu reliabel. Dalam variabel ini setiap pernyataan dan jawaban konsisten.

3. Stres, nilai yang dihasilkan oleh variabel ini sebesar 0,760. Sesuai dengan ketentuan yaitu 0,760 lebih besar dari 0,60 sehingga hasil dari variabel tanggap dalam pengujian ini yaitu reliabel. Dalam variabel ini setiap pernyataan dan jawaban konsisten.

4. Prestasi Akademik, nilai yang dihasilkan oleh variabel ini sebesar 0,735 . Sesuai dengan ketentuan yaitu 0,735 lebih besar dari 0,60 sehingga hasil dari variabel tanggap dalam pengujian ini yaitu reliabel. Dalam variabel ini setiap pernyataan dan jawaban konsisten.

Dapat disimpulkan berdasarkan analisis yang telah dilakukan bahwa dari seluruh pernyataan-pernyataan yang ada telah memenuhi ketentuan dengan memiliki nilai Cronbach's Alpha lebih besar dari 0,60 yang menjadikan hasil dari tiap variabel yaitu Adversity Quotient, Emotional Quotient, Stres dan Prestasi Akademik dinyatakan reliabel. Variabelvariabel yang dinyatakan reliabel memiliki kekonsistensian antara pernyataan dan jawaban yang diberikan responden.
3. Hasil Uji Regresi Linier Berganda Hasil Uji Regresi Linear Berganda

\begin{tabular}{|c|l|}
\hline \multirow{2}{*}{ Model } & \multicolumn{2}{|c|}{ Unstandardized Coefficients } \\
\cline { 2 - 2 } & \multicolumn{1}{|c|}{ B } \\
\hline (Constant) & 0,878 \\
\hline ADVERSITY_QUOTIENT & 0,208 \\
\hline EMOTIONAL_QUOTIENT & 0,028 \\
\hline STRES & 0,454 \\
\hline \multicolumn{2}{|c|}{ Sumber: Data Primer, 2018}
\end{tabular}

Berdasarkan hasil tersebut dapat diperoleh persamaan regresi sebagai berikut:

$$
\begin{aligned}
& \mathrm{Y}=\mathrm{a}+\mathrm{b} 1 \mathrm{X} 1+\mathrm{b} 2 \mathrm{X} 2+\mathrm{b} 3 \mathrm{X} 3+\mathrm{e} \\
& \mathrm{Y}=0,878+0,208 \mathrm{X} 1+0,028 \mathrm{X} 2+ \\
& 0,454 \mathrm{X} 3+\mathrm{e}
\end{aligned}
$$

Setiap nilai dari persamaan regresi diatas dapat diinterpretasikan yaitu :

$\mathrm{a}=0,878$ merupakan nilai constant atau intersep. Jika nilai dari variabel bebas X1, X2 dan X3 sama dengan 0 maka nilai $Y$ adalah 0,878 .

b1 $=0,208$ koefisien bernilai positif artinya terjadi hubungan positif antara adversity quotient (X1) dengan prestasi akademik (Y). Jika nilai adversity quotient $(\mathrm{X})$ semakin besar maka nilai prestasi akademik (Y) semakin semakin besar. Koefisien adversity quotient (X) sebesar 0,208 artinya jika nilai variabel independen lainnya tetap dan jika variabel adversity quotient (X) mengalami kenaikan 1 satuan maka prestasi akademik (Y) naik sebesar 0,208 .

b2 $=0,028$ koefisien bernilai positif artinya terjadi hubungan positif antara antara emotional quotient (X2) dengan prestasi akademik (Y). Jika nilai emotional quotient (X2) semakin besar maka nilai prestasi akademik (Y) semakin besar. Koefisien emotional quotient (X2) sebesar 0,028 artinya jika nilai variabel independen lainnya tetap dan jika variabel emotional quotient (X2) mengalami kenaikan 1 satuan maka prestasi akademik (Y) naik sebesar 0,028 . 
b3 $=0,454$ koefisien bernilai positif artinya terjadi hubungan positif antara antara stres (X3) dengan prestasi akademik (Y). Jika nilai stres (X3) semakin besar maka nilai prestasi akademik (Y) semakin besar. Koefisien stres (X3) sebesar 0,454 artinya jika nilai variabel independen lainnya tetap dan jika variabel stres (X3) mengalami kenaikan 1 satuan maka prestasi akademik (Y) naik sebesar 0,454.

\section{Hasil Uji Parsial (Uji T)}

\section{Hasil Uji Parsial (Uji T) Model 1}

Uji t digunakan untuk mengetahui seberpa besar atau signifikansi pengaruh variabel independen (X1 : (Adversity Quotient) secara parsial / individual terhadap variabel dependen (Y : Prestasi Akademik).

Hasil uji signifikansi Parsial (Uji T)

\begin{tabular}{|l|l|}
\hline \multirow{2}{*}{ Variabel } & Hasil $\mathrm{Uji}$ \\
\cline { 2 - 2 } & Sig. \\
\hline Adversity Quotient & 0,038 \\
\hline
\end{tabular}

Sumber: Data Primer, 2018

Berdasarkan uji signifikansi yang dihasilkan uji parsial dapat dijelaskan bahwa variabel adversity quotient mempunyai nilai signifikan $0,038<0,05$. Maka dapat disimpulkan bahwa secara individual variabel adversity quotient berpengaruh signifikan terhadap prestasi akademik.

Hasil Uji Parsial (Uji T) Model 2

Uji t digunakan untuk mengetahui seberapa besar atau signifikansi pengaruh variabel independen (X2 : Emotional Quotient) secara parsial / individual terhadap variabel dependen (Y: Prestasi Akademik).

Hasil Uji Signifikansi Parsial (Uji T)

\begin{tabular}{|l|l|}
\hline \multirow{2}{*}{ Variabel } & Hasil Uji \\
\cline { 2 - 2 } & Sig. \\
\hline Emotional Quotient & 0,434 \\
\hline
\end{tabular}

Berdasarkan output uji t, variabel emotional quotient mempunyai nilai signifikan 0,434 >0,05. Maka dapat disimpulkan bahwa secara individual / parsial variabel emotional quotient tidak berpengaruh signifikan terhadap prestasi akademik.

Hasil Uji Parsial (Uji T) Model 3

Uji t digunakan untuk mengetahui seberapa besar atau signifikansi pengaruh variabel independen (X3 : Stres) secara parsial / individual terhadap variabel dependen (Y: Prestasi Akademik).

\begin{tabular}{|l|l|}
\hline \multirow{2}{*}{ Variabel } & Hasil Uji \\
\cline { 2 - 2 } & Sig. \\
\hline Stres & 0,000 \\
\hline \multicolumn{2}{|c|}{ Sumber: Data Primer, 2018}
\end{tabular}

Berdasarkan output uji t, variabel stres mempunyai nilai signifikan $0,000<$ 0,05 . Maka dapat disimpulkan bahwa secara individual / parsial variabel stres berpengaruh signifikan terhadap prestasi akademik.

\section{Hasil Uji Simultan (Uji F)}

Hasil Uji Signifikansi Bersama-sama (Uji F)

\begin{tabular}{|l|l|l|}
\hline Variabel & & Hasil Uji \\
\cline { 2 - 3 } & F & Sig. \\
\hline $\begin{array}{l}\text { Adversity Quotient } \\
\text { Emotional Quotient } \\
\text { Stres }\end{array}$ & 67,998 & 0,000 \\
\hline & & \\
\hline \multicolumn{2}{|c|}{ Sumber: Data Primer, 2018 } \\
\hline
\end{tabular}

Dari hasil uji regresi linear berganda di peroleh $\mathrm{F}$ hitung sebesar 67,998 dengan probabilitas $0,000<$ 0,05 . Jika dibandingkan dengan alpha 0,05 , maka $0,000<0,05$ yang artinya variabel AQ,EQ dan stress secara bersama-sama berpengaruh signifikan terhadap variabel prestasi akademik. Sehingga dapat disimpulkan bahwa $\mathrm{Ha}$ diterima dan Ho ditolak.

6. Hasil Uji Koefisien Determinasi

Dari hasil output hasil analisis uji $\mathrm{R}$ Square, diketahui nilai koefisien determinasi (R Square) sebesar 0,417 Besarnya angka koefisien determinasi (R Square) 0,417 sama dengan 41,7\%. 
Angka tersebut memiliki arti bahwa variabel variabel independen (X1 : Adversity Quotient, X2 : Emotional Quotient, X3 : Stres) mampu menjelaskan variabel dependen (Y : Prestasi Akademik) sebesar 41,7\%. Sedangkan sisanya $(100 \%-41,7 \%=$ $58,3 \%$ ) dijelaskan oleh variabel lain yang tidak diteliti dalam penelitian ini.

Hasil perhitungan koefisien determinasi

\begin{tabular}{|l|l|}
\hline Model & R Square \\
\hline Adversity Quotient & \\
Emotional Quotient & \\
Stres & 0,417 \\
\hline
\end{tabular}

Sumber: Data Primer, 2018

\section{Pembahasan}

\section{Pengaruh Adversity Quotient terhadap Prestasi Akademik}

Dari uji hipotesis yang dilakukan bahwa adversity quotient mempunyai pengaruh yang signifikan positif terhadap prestasi akademik, artinya Ha diterima hal ini dapat ditunjukkan dengan nilai sig < alpha yaitu $(0,038<0,05)$. Hal ini menunjukkan bahwa adversity quotient menentukan tingkat prestasi akdemik mahasiswa yang mengikuti organisasi di Universitas Ahmad Dahlan.

Pada mahasiswa yang mengikuti organisasi mahasiswa di Universitas Ahmad Dahlan, adversity quotient sangat berpengaruh terhadap prestasi akademiknya, dimana mahasiswa yang mengikuti organisasi berjuang untuk menyelesaikan semua tugas dan masalahmasalah di dalam organisasi dengan baik agar hal tersebut tidak berpengaruh terhadap prestasi akademik mereka di perkuliahan.

Hal tersebut juga didukung oleh hasil data kuisioner yang diperoleh dari responden mahasiswa yang mengikuti organisasi mahasiswa DPM, BEM, HMPS dan UKM pada variabel adversity quotient terdapat 3 item pernyataan yang memiliki respon tidak setuju, setuju dan sangat setuju, diantaranya pada item 4 dan 8 tidak setuju sebanyak 17 responden atau sebesar 5,88\% apabila di persentasekan. Nomer item 6 sebanyak 177 responden menjawab setuju atau $61,25 \%$ jika di persentasekan. Sedangkan untuk sangat setuju sebanyak 175 atau $60,55 \%$ pada item 12 .

Hasil penelitian ini mendukung penelitian terdahulu pada penelitian Huda 2013 pada studi kasus di Fakultas Psikologi UIN SGD Bandung, dimana hasil tersebut menghasilkan signifikan sebesar 0,029 < 0,05 dengan sampel sebanyak 109 mahasiswa. Dapat disimpulkan dari penjelasan di atas maka menghasilkan signifikan antara variabel adversity quotient terhadap prestasi akademik.

\section{Pengaruh Emotional Quotient terhadap prestasi akademik \\ Dari uji hipotesis yang dilakukan} pada penelitian ini bahwa Emotional Quotient tidak mempunyai pengaruh yang signifikan terhadap prestasi akademik, yang artinya bahwa Ha ditolak hal ini dapat dilihat dari nilai signya sebesar $0,434>0,05$. Tidak signifikan karena Emotional Quotient tidak menentukan tingkat prestasi akademik mahasiswa yang mengikuti organisasi mahasiswa di Universitas Ahmad Dahlan.

Pada mahasiswa yang mengikuti organisasi di Universitas Ahmad Dahlan, Emotional Quotient tidak berpengaruh secara signifikan terhadap prestasi akademik, hal ini bisa di sebabkan oleh kurangnya mahasiswa dalam mengontrol emosinya saat terjadi masalah pribadi atau masalah di

dalam organisasinya, jika mahasiswa tidak dapat mengontrol emosionalnya maka dapat berpengaruh kepada kuliahnya sehingga prestasi akademiknya dapat menurun.

Hal tersebut juga didukung oleh hasil data kuisioner yang diperoleh dari responden mahasiswa yang mengikuti organisasi mahasiswa DPM, BEM, HMPS dan UKM pada variabel emotional quotient terdapat 3 item pernyataan yang memiliki respon tidak setuju, setuju dan sangat setuju, diantaranya pada item 6 
tidak setuju sebanyak 9 responden atau sebesar $3,1 \%$ apabila di persentasekan. Nomer item 16 sebanyak 96 responden menjawab setuju atau $33,2 \%$ jika di persentasekan. Sedangkan untuk sangat setuju sebanyak 194 atau $67 \%$ pada item 10.

Hasil penelitian ini sesuai penelitian terdahulu pada penelitian Putra 2012 pada studi kasus di Keperawatan PSIK-FK Universitas Syiah Kuala Banda Aceh, dimana hasil tersebut menghasilkan tidak signifikan sebesar $0,379>0,05$ dengan sampel sebanyak 77 mahasiswa. Dapat disimpulkan dari penjelasan di atas maka menghasilkan tidak signifikan antara variabel Emotional Quotient terhadap prestasi akademik.

\section{Pengaruh Stres terhadap Pretasi akademik}

Dari uji hipotesis yang dilakukan bahwa stres mempunyai pengaruh yang signifikan positif terhadap prestasi akademik, artinya $\mathrm{Ha}$ diterima hal ini dapat ditunjukkan dengan nilai sig < alpha yaitu $(0,000<0,05)$. Hal ini menunjukkan bahwa stres menentukan tingkat prestasi akdemik mahasiswa yang mengikuti organisasi di Universitas Ahmad Dahlan. Stres yang positif disini sesuai dengan yang dikatakan "Ifdil dan Taufik (2012:115) menyebutkan Guru BK memiliki peran penting dalam membantu siswa mengenal dan mengatasi stres akademik yang muncul pada diri siswa. Layanan yang dapat dikembangkan seperti layanan informasi tentang stres dan cara mengatasinya, jika pada mahasiswa dapat konsultasi pada sikologi. Senada dengan dikemukakan oleh Barseli, M., dan Ifdil, I. (2017) stres akademik adalah pikiran dan emosi negative yang muncul karena adanya tuntutan. Siswa yang dapat mengindar hal tersebut maka kemungkinan besar terhindar dari stres akademik

Pada mahasiswa yang mengikuti organisasi mahasiswa di Universitas Ahmad Dahlan, stres sangat berpengaruh terhadap prestasi akademiknya, dimana mahasiswa yang mengikuti organisasi berjuang untuk menyelesaikan semua tugas dan masalah-masalah di dalam organisasi dengan baik agar hal tersebut tidak berpengaruh terhadap prestasi akademik mereka di perkuliahan.

Hal tersebut juga didukung oleh hasil data kuisioner yang diperoleh dari responden mahasiswa yang mengikuti organisasi mahasiswa DPM, BEM, HMPS dan UKM pada variabel adversity quotient terdapat 3 item pernyataan yang memiliki respon tidak setuju, setuju dan sangat setuju, diantaranya pada item 1 tidak setuju sebanyak 9 responden atau sebesar $3,11 \%$ apabila di persentasekan. Nomer item 7 sebanyak 79 responden menjawab setuju atau 27,3\% jika di persentasekan. Sedangkan untuk sangat setuju sebanyak 126 atau 43,60\% pada item 10.

Hasil penelitian ini sesuai penelitian terdahulu pada penelitian $\mathrm{S}$. Zubeidi 2015 pada studi kasus di Jurusan Akuntansi Universitas Hasanuddin Makassar, dimana hasil tersebut menghasilkan signifikan sebesar $0,000<$ 0,05 dengan sampel sebanyak 82 mahasiswa. Dapat disimpulkan dari penjelasan di atas maka menghasilkan signifikan antara variabel stres terhadap prestasi akademik.

\section{Pengaruh Adversity Quotient, Emotional Quotient dan Stres terhadap Prestasi Akdemik}

Dari hasil analisis diketahui bahwa Adversity Quotient, Emotional Quotient dan stres secara bersama-sama berpengaruh signifikan positif terhadap prestasi akademik bagi mahasiswa yang mengikuti organisasi mahasiwa di Universitas Ahmad Dahlan hal ini dapat dilihat dari nilai signya $0,000<0,05$ sehingga menerima Ha. 


\section{KESIMPULAN DAN SARAN}

\section{Kesimpulan}

Berdasarkan hasil pembahasan yang telah dijelaskan pada bab sebelumnya, maka dapat ditarik kesimpulan sebagai berikut:

1. Variabel Adversity Quotient berpengaruh secara signifikan terhadap Prestasi Akademik hal itu ditunjukkan pada hasil uji t sebesar 0,038 . Hal ini menunjukkan bahwa Adversity Quotient pada mahasiswa yang mengikuti organisasi di Universitas Ahmad Dahlan berpengaruh terhadap Prestasi Akademik.

2. Variabel Emotional Quotient tidak berpengaruh secara signifikan terhadap Prestasi Akademik hal itu ditunjukkan pada hal uji $\mathrm{t}$ sebesar 0,434 . Hal ini menunjukkan bahwa Emotional Quotient pada mahasiswa yang mengikuti organisasi di Universitas Ahmad Dahlan tidak berpengaruh terhadap Prestasi Akademik.

3. Variabel Stres berpengaruh secara signifikan terhadap Prestasi Akademik hal itu ditunjukkan pada hasil uji t sebesar 0,000. Hal ini menunjukkan bahwa Stres pada mahasiswa yang mengikuti organisasi di Universitas Ahmad Dahlan berpengaruh terhadap Prestasi Akademik.

4. Sedangkan pada hasil uji F, dapat simpulkan bahwa Adversity Quotient, Emotional Quotient, dan Stres berpengaruh terhadap Prestasi Akademik bagi mahasiswa yang mengikuti organisasi mahasiswa di Universitas Ahmad Dahlan secara bersama-sama (simultan), hal ini ditunjukkan dengan nilai hasil uji $\mathrm{F}$ yaitu sebesar $0,000<0,05$.

\section{Saran}

Adapun beberapa saran yang perlu dipertimbangkan dalam penyusunan penelitian ini adalah sebagai berikut:

1. Saran buat seluruh mahasiswa yang mengikuti organisasi mahasiwa agar dapat mengisi kuesioner dengan baik dan jujur dan cepat dimana hal ini akan dapat membantu peneliti dengan baik dan cepat dalam memproses data.

2. Buat penelitian yang selanjutnya agar teori-teori yang digunakan di perbanyak dan teori-teori yang terbaru agar memperkuat penelitian selanjutnya.

3. Peneliti selanjutnya disarankan agar dapat mengukur kriteria Prestasi Akademik yang lebih baik.

4. Peneliti selanjutnya agar dapat melakukan penelitian di institusi atau perguruan tinggi lainnya karena setiap institusi berbeda sistem atau keadaannya.

5. Untuk penelitian selanjutnya jika ingin meneliti sama seperti peneliti agar dapat menambahkan studinya seperti perbedaan mahasiswa yang mengikuti organisasi dengan mahasiswa yang tidak mengikuti organisasi

\section{DAFTAR PUSTAKA}

Departemen Agama, 1990, Al Quran dan Terjemah. Jakarta Diana Nida'u. 2008. "Study Deskriptif Tentang Adversity Quotient Pada Siswa Kelas Akselerasi (studi kasus pada Sekolah Menengah Atas Negeri 1 Malang)". Skripsi. Malang. Fakultas Psikologi: Universitas Islam Negeri Malang.

Fachrosi Erlyani. 2012. "Perbedaan Stres Akademik antara Kelompok Siswa Minoritas dengan Mayoritas di SMP WR. SUPRATMAN 2 MEDAN". Penelitian. Medan: Universitas Sumatera Utara. 
Kementrian pendidikan. Didapatkan: http:www.Belmawa.ristekdikti.go.id

Lismarni. 2013. "Pengaruh Kecerdasan Emosional Terhadap Prestasi Belajar Mahasiswa D-III Kebidanan STIKES Prima Nusantara Bukittinggi” Jurnal Kesehatan STIKes Prima Nusantara Bukittinggi(Juli), Vol.7 No.2 2016.

Mulyana Agus dan Tesa N. Huda. 2013. “ Pengaruh Adversity Quotient terhadap Prestasi Akademik Mahasiswa Angkatan 2013 Fakultas Psikologi UIN SGD Bandung" Jurnal Ilmiah Psikologi Vol.4 No.1, 2018: Hal 115-132. eISSN:25022903, pISSN: 2356-3591, DOI: 10.15575/psy.v4i1.1336.

Nuryadin Rusmin. 2013. "Pengaruh Kecerdasan Emosi dan Stress Terhadap Prestasi Belajar Mahasiswa Jurusan Manajemen Ekstensi Fakultas Ekonomi Universitas Mulawarman".

Putra Ardia. 2012. "Hubungan Kecerdasan Emosional dengan Prestasi Akademik pada Mahasiswa Keperawatan di Banda Aceh" Idea Nursing Journal ISSN:2087-2879. Vol.III No.3.

Rahmi Nuzulul. 2013. "Hubungan Tingkat Stres dengan Prestasi Belajar Mahasiswa Tingkat II Prodi D-III Kebidanan Banda Aceh Jurusan Kebidanan Poltekkes Kemenkes NAD TA. 2011/2012" Jurnal Ilmiah STIKes U'Budiyah(Maret), Vol.2, No.1.

S. Zubeidi Fatmah Fildzah. 2015. "Pengaruh Stres, Motivasi, Dan Kecerdasan Spiritual Terhadap Prestasi Belajar (studi pada Mahasiswa Jurusan Akuntansi Universitas Hasanuddin)". Skripsi. Makassar. Fakultas Ekonomi dan
Bisnis: Universitas Hasanuddin Makassar.

Stolz. G poul. Adversity Quotient.2000. Mengubah Hambatan Menjadi Peluang. Jakarta. Grasindo.

Sugiyono. 2014. Metode Penelitian Bisnis (Pendekatan Kuantitatif, Kualitatif, dan R\&D). Bandung. Alfabeta.

Usman Nuni Uciaty. 2010. "Hubungan Stres Dengan Indeks Prestasi Mahasiswa Keperawatan Di Universitas Islam Negeri Alauddin Makassar Tahun 2010". Skripsi. Makassar:Universitas Islam Negeri Alauddin.

Wardani, Laurae, Populasi dan Sampel, [Online] Didapatkan:

https://lauraewardani.blogspot.com/2 014/05/populasi-dan sampel.html? $\mathrm{m}=1$ [11>Mei2014]. 